\title{
Biofilm and Related Amoebas in an UK Chlorinated Drinking Water System
}

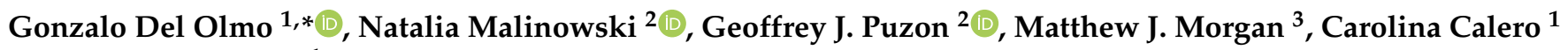 \\ and Isabel Douterelo ${ }^{1, *}$ \\ 1 Civil and Structural Engineering Department, University of Sheffield, Sheffield S1 3JD, UK; \\ c.calerop@gmail.com \\ 2 CSIRO Land and Water, 147 Underwood Avenue, Perth, WA 6014, Australia; \\ Natalia.Malinowski@csiro.au (N.M.); Geoffrey.puzon@csiro.au (G.J.P.) \\ 3 CSIRO Land and Water, Black Mountain Laboratories, Canberra, ACT 2601, Australia; \\ Matthew.Morgan@csiro.au \\ * Correspondence: g.del-olmo@sheffield.ac.uk (G.D.O.); i.douterelo@sheffield.ac.uk (I.D.)
}

check for updates

Citation: Del Olmo, G.; Malinowski, N.; Puzon, G.J.; Morgan, M.J.; Calero, C.; Douterelo, I. Biofilm and Related Amoebas in an UK Chlorinated Drinking Water System. Water 2021 13, 3069. https://doi.org/10.3390/ w13213069

Academic Editor: Xuezhi Zhang

Received: 16 September 2021

Accepted: 30 October 2021

Published: 2 November 2021

Publisher's Note: MDPI stays neutral with regard to jurisdictional claims in published maps and institutional affiliations.

Copyright: (c) 2021 by the authors. Licensee MDPI, Basel, Switzerland. This article is an open access article distributed under the terms and conditions of the Creative Commons Attribution (CC BY) license (https:// creativecommons.org/licenses/by/ $4.0 /)$.

\begin{abstract}
Drinking water distribution systems (DWDS) can host pathogenic amoebae, but the role of biofilms in supporting the occurrence of these organisms needs to be fully explored in the UK systems. The presence of amoebae and associated bacteria in biofilms attached to inner pipe surfaces was studied in an experimental full-scale chlorinated distribution system in the UK. Quantitative polymerase change reaction (qPCR) was used to identify and quantify amoebae, whilst the bacterial communities in the biofilms were characterised by sequencing the 16S rRNA gene. Despite the maintenance of a chlorine residual in the network (free chlorine $\geq 0.24 \mathrm{mg} / \mathrm{L}$ ), several species of amoebae belonging to the genera Acanthamoeba, Vermamoeba, and Naegleria were identified in 30-day-old biofilm samples; however, no amoebae were detected in the water samples analysed. The dominant bacterial communities present in the biofilm samples were Variovorax, Pseudomonas, and Aquabacterium. These results indicate that the biofilm samples contained potential pathogenic amoebae and bacteria, such as Acanthamoeba and Pseudomonas, respectively, which implies a potential public health risk if the biofilms are mobilised into the bulk water. Several of the amoebae identified in this study are able to support the presence of resistant bacteria that can remain viable within these prokaryotic organisms until they reach people's taps. The identification of the microorganisms associated with the pathogenic amoeba species in biofilms could be used to improve the surveillance of DWDS in order to protect public health.
\end{abstract}

Keywords: amoeba; water; water quality bacteria; biofilm; chlorination; drinking water

\section{Introduction}

Free-living amoebae (FLA) are unicellular eukaryotic organisms classified as protists that can grow in different natural and man-made environments, including soil, marine water, fresh water, eyewash stations, swimming pools, and drinking water distribution systems (DWDS) [1,2]. The life cycle of FLA usually comprises a vegetative form, called a trophozoite, and a resting form, called a cyst. However, some amoebae, such as Naegleria spp., have an additional flagellate stage, and others, such as Mayorella and Amoeba, are noncyst-forming species [3]. Among the organisms considered as FLA, members of the genera Acanthamoeba, Naegleria, Vermamoeba, Sappinia, and Balamuthia have been recognised as etiologic agents of encephalitis (Naegleria fowleri, Acanthamoeba spp., Balamuthia mandrillaris, and Sappinia diploidea) and/or responsible for amoebic keratitis (Acanthamoeba spp. and Vermamoeba vermiformis, previously known as Hartmannella vermiformis) [4-6].

Since the 1970s, the United Kingdom (UK) has been registering cases of diseases caused by pathogenic amoebae, such as primary amoebic meningoencephalitis (PAM), produced by Naegleria fowleri [7,8], and Acanthamoeba keratitis (AK), a corneal infection 
produced mainly by members belonging to the Acanthamoeba genus [9-17]. These diseases have been on the rise and are potentially fatal if not accurately diagnosed and promptly treated $[5,18,19]$. PAM is a fulminating infection of the central nervous system that has a mortality rate of $97 \%$. Due to the rapid onset of the symptoms and disease progression, PAM is commonly diagnosed post-mortem [20]. In AK disease, amoebae are introduced to the cornea during trauma or the improper care of contact lenses. The amoebae feed on keratocytes, resulting in corneal ulceration, photophobia, pain, and enucleation of the eye in the worst-case scenario [5].

Cases of diseases caused by FLA have been increasingly linked to DWDS. PAM cases have been associated with ritual ablutions using municipal water in Pakistan, backyard hoses, and community water parks in the United States of America (USA), and overland water systems in Australia [21-23], whereas AK cases have been commonly associated with the improper care of contact lenses when preparing homemade saline solutions using contaminated tap or distilled water [24,25]. The AK incidence in the UK is higher overall than in the rest of Europe and the USA [11], with a 15 times higher incidence rate than the USA and a seven times higher rate than in the Netherlands [12]. Recently, AK has been described as an outbreak based on the data provided by Moorfields Eye Hospital. There has been an average of 53 cases per year between 2012 and 2016, which is three times higher than the decade before (2000-2010) [15].

The presence of pathogenic FLA in DWDS is favoured by a number of physical and chemical factors, such as the increased distance from the disinfection site, reduction of residual chlorine, water hardness, and higher water temperatures, as well as factors that may also be site-specific, such as network infiltration rates, the pipe material used, and/or hydrodynamic properties $[11,17,26,27]$. The biological factors associated with FLA presence are not well understood; however, increased bacterial richness has been shown to be associated with $N$. fowleri presence [28]. Moreover, several studies have indicated that pipe wall biofilms, which represent more than 95\% of the total biomass in DWDS [29], are able to support the growth of amoebae by providing a food source and protecting them against disinfectants, such as chlorine [26]. By feeding on the microbial layers within biofilm, not only can amoebae continue to persist but they can also further enhance bacterial productivity by nutrient cycling and prey pressure [30]. Although pathogenic amoebae previously were found mostly in warmer areas, climate change appears to be contributing to their geographic spread [31,32].

Not only are FLA a risk due to their inherent pathogenicity but they also have a number of associated endosymbionts, including viruses, yeast, protists, and bacteria, of which some are potential human pathogens $[4,5,33]$. Thus, FLA can act as "Trojan horses" for pathogens, offering an environment in which these organisms are protected from the physical (predation from other protozoa) and chemical (reducing efficacy of chemical disinfectants) conditions that would normally prevent their survival $[1,30,34]$. This strategy could mobilise hidden pathogens, increasing their transmission potential. Amoebae resistant bacteria (ARB) are able to resist death by phagocytosis and benefit from interactions with FLA. There is a wide diversity of these ARB; however, some of these bacteria have been described as human pathogens, such as Staphylococcus aureus, Listeria monocytogenes, Salmonella spp., Vibrio cholerae, Helicobacter pylori, Legionella pneumophila, Mycobacterium avium, or Pseudomonas aeruginosa [35-38]. Mounting evidence suggests that FLA increase both the number and virulence of intracellular bacteria, allowing for increased rates of infectivity and intracellular replication [39-41]. Numerous studies have investigated these interactions in vitro, but more evidence is needed on how these interactions occur in the environment.

FLA continue to be relevant contributors to waterborne disease, and the increasing prevalence and detection of these pathogens is driving the need for a better understanding of their interactions with the environment, other organisms, and associated pathogenic bacteria. Assessing and understanding the relationships and interactions between FLA and the surrounding microbial community is integral to ensure the continued safety of 
water systems and to maintain public health. In order to improve the knowledge of these interactions, this research aims to identify the viability of amoebae in biofilms using a UK full scale DWDS facility, representative of real-world environments in distribution networks, as well as exploring possible interactions between bacterial communities. The results will inform water utilities on the possible risks associated with bacteria and amoebae in biofilms and improve the management strategies for maintaining water quality standards by controlling microbial growth.

\section{Materials and Methods}

\subsection{Experimental Facility and Conditions}

The experiment was carried out using a DWDS test facility at the University of Sheffield, UK (Figure 1A). The facility has 3 independent loops of $9.5 \mathrm{~m} \times 21.4 \mathrm{~m}$ long coils of high-density polyethylene (HDPE) pipe with an internal diameter of $79.3 \mathrm{~mm}$. Each loop is connected to its own enclosed reservoir tank, which is fed with water from the local DWDS. From each tank, water can be recirculated in each loop at different flow rates and pressure using individual speed pumps and valves that are controlled by a central computer to enable simulation of real hydraulic demand patterns.

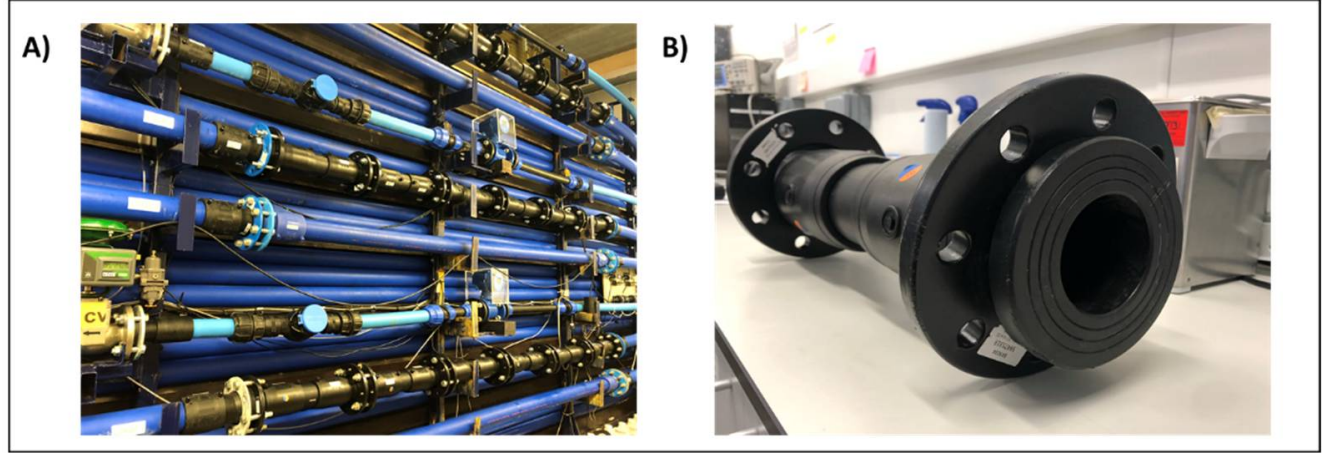

Figure 1. (A) Full scale experimental DWDS facility composed of 3 individual loops; (B) removable pipe sections used for biofilm sampling.

To enable the in situ sampling of biofilms developed in the pipe walls, each loop has 6 removable HDPE pipe sections of $0.5 \mathrm{~m}$ in length (Figure 1B). Before the experiment started, the whole facility was disinfected with $20 \mathrm{mg} / \mathrm{L}$ of RODOLITE H (RODOL Ltd., Liverpool, UK), a sodium hypochlorite-based solution with less than $16 \%$ free chlorine. The pipes were flushed at a maximum flow rate $(4.2 \mathrm{~L} / \mathrm{s})$ and left standing for $24 \mathrm{~h}$ with the disinfectant. Then, the facility was flushed again at the maximum flow rate with fresh tap water until the levels of free chlorine were within the limit recommended by the World Health Organization (no greater than $5 \mathrm{mg} / \mathrm{L}$ ) [42] and showed close values to the tap water entering the system $(\approx 0.2 \mathrm{mg} / \mathrm{L})$.

To achieve the objectives of this research, the 3 loops were operated under the same conditions for a growth phase of 30 days to allow for the biofilm development in the internal pipe walls. For this growth phase, a low varied flow hydraulic profile that follows daily patterns observed in real DWDS in the UK was applied. The regimen follows a typical domestic dominated diurnal pattern with nighttime low flow of $0.2 \mathrm{~L} / \mathrm{s}$ and morning peak flow of $0.5 \mathrm{~L} / \mathrm{s}$ [43].

\subsection{Water Physico-Chemistry}

Water quality parameters were measured to obtain information about the inner pipe environment. Measurements were taken at the beginning of the experiment, every 10 days during the growth phase, and at each sampling point using discrete triplicate water samples $(n=3)$ by sampling ports connected to each loop. Water temperature and $\mathrm{pH}$ were tested using a Hanna portable meter HI 991003 (Hanna Instruments, Leighton Buzzard, UK), and free and total chlorine concentrations were tested using a Palintest CS100 chlorosense 
(Palintest, Gateshead, UK). Water turbidity was measured using a Palintest compact turbidity meter QuadoptiX ${ }^{\mathrm{TM}}$ (Palintest, UK). All measurements were taken following the manufacturers' protocols.

\subsection{Microbial Communities Sampling}

Planktonic communities were assessed by collecting $10 \mathrm{~L}$ bulk water samples from each loop by means of sampling ports. Samples were then concentrated down to $500 \mathrm{~mL}$ using a tangential flow filtration (TFF) system (PALL Life Science, New York, NY, USA), and 3 aliquots of $10 \mathrm{~mL}$ were taken for microbial community analysis. Each of the loops also contained 6 removable $0.5 \mathrm{~m}$ long HDPE pipe sections (Figure 2) to enable in situ sampling of pipe wall biofilm. At the end of the experiment (day 30), 3 of these pipe sections were removed from each loop, for a total of 9 biological replicates. A total biofilm area of $375 \mathrm{~cm}^{2}$ (15 cm long of each section) was removed from each pipe section using a sterile nylon brush and a standardised brushing protocol [44] and resuspended in $5 \mathrm{~mL}$ of bulk water collected from the pipe facility. The concentrated bulk water and biofilm samples were then sent to CSIRO Land and Water (Floreat, WA, USA) for further analysis.

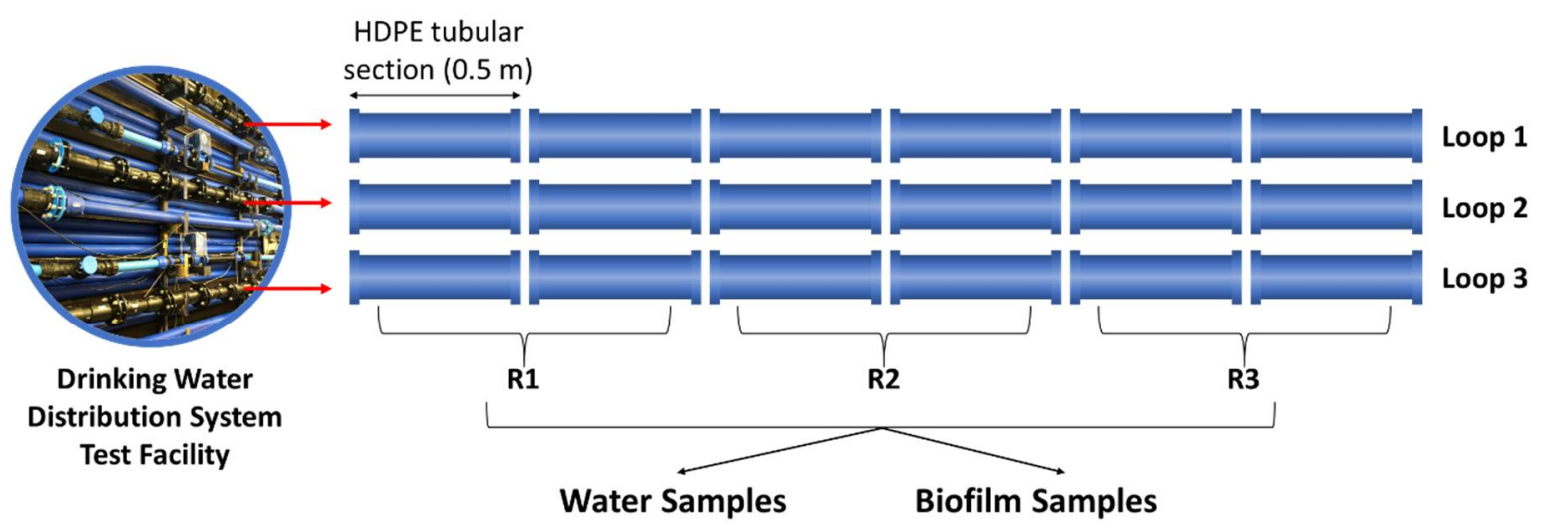

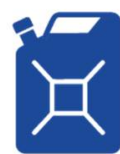

$10 \mathrm{~L}$ of bulk water filtered using Tangential Flow Filtration

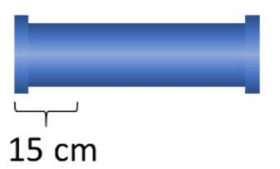

$15 \mathrm{~cm}$

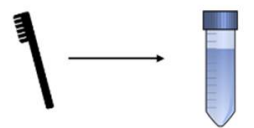

Pipe area $5 \mathrm{~mL}$ of bulk brushed: water $375 \mathrm{~cm}^{2}$

Figure 2. Schematic representation of planktonic and biofilm microbial communities sampling.

\subsection{Analysis of Microbial Communities and Amoebae Presence}

The total microbial community concentrations were analysed by flow cytometry using methods previously described by Miller et al. (2015) [45]. The remaining bulk water and biofilm samples were divided into two equal portions. One portion was used for viable amoebae analysis using our previously published protocol [28,46-48]. In short, samples were concentrated by centrifugation at $2000 \times g$ for $10 \mathrm{~min}$, supernatant decanted, and pellets resuspended in $1.5 \mathrm{~mL}$ of $25 \%$ Ringers solution (Oxid Corp., Farmington Hills, MI, USA). The sample (500 $\mu \mathrm{L}$ per plate) was plated onto three non-nutrient agar plates coated with Escherichia coli (NNA-E. coli) and incubated separately at $42{ }^{\circ} \mathrm{C}, 30^{\circ} \mathrm{C}$, and room temperature (RT) $\sim 22{ }^{\circ} \mathrm{C}$. Positive plates were scraped, and DNA was extracted using Bio-Rad InstaGene matrix (BioRad, Hercules, CA, USA) following manufacturer's protocol to identify amoebae as previously reported [28,46-48]. The second portion was concentrated by centrifugation $(10,000 \times g$ for $5 \mathrm{~min})$ for biofilm and filtered $(0.22 \mu \mathrm{m})$ for 
bulk water and used for total DNA extraction. Total DNA from biofilm and bulk water was extracted using either Qiagen DNeasy PowerSoil kit (biofilm) or Qiagen DNeasy PowerWater DNA Isolation kit (bulk water) (Qiagen, Germantown, MD, USA) according to the manufacturer's protocol and stored at $-20{ }^{\circ} \mathrm{C}[28,46-48]$. InstaGene and total DNA extractions were then used for the molecular detection of amoebae by qPCR melt-curve analysis. Methods for Naegleria species identification by qPCR melt curve analysis along with reaction concentrations, primers, and PCR cycle conditions were performed as previously described [46]. Samples were run in triplicate with either an N. fowleri specific primer set or a consensus primer set for Naegleria spp. and Vermamoeba spp. [49]. Acanthamoeba spp. specific primers [50] were used to amplify DNA samples using following PCR conditions modified from Schroeder et al. 2001: initial denaturing step of $15 \mathrm{~min}$ at $95^{\circ} \mathrm{C}$, followed by 45 cycles of $95^{\circ} \mathrm{C} 30 \mathrm{~s}, 60{ }^{\circ} \mathrm{C} 1 \mathrm{~min}, 72{ }^{\circ} \mathrm{C} 2 \mathrm{~min}$, and with a $6 \mathrm{~s}$ pause at $80{ }^{\circ} \mathrm{C}$ for fluorescent dye detection. Positive controls (target DNA) and negative (RNase-free $\mathrm{H}_{2} \mathrm{O}$ and DNA extraction blanks) controls were included in each qPCR experiment.

\subsection{Assessment of the Microbial Community Composition}

Microbial community composition of biofilm sample and controls was assessed by sequencing a 300 bp amplicon targeting the V4 region of the 16S rRNA gene using total DNA extracted from the biofilm samples as previously reported [47,51]. Amplicons were generated using gene-specific primers (in bold) with the appropriate adapter sequence for Illumina sequencing (in italics) 515f (5'-TCGTCGGCAGCGTCAGATGTGTATAAGAGACAGGT GCCAGCMGCCGCGGTAA-3') and 806rbc (5'-GTCTCGTGGGCTCGGAGATGTGTATAA GAGACAGGGACTACHVGGGTWTCTAAT-3') (IDT, Coralville, IA, USA). Samples were first amplified individually using Platinum Taq (Invitrogen, Waltham, MA, USA) according to the Illumina amplicon sequencing protocol (Illumina, San Diego, CA, USA) using the following PCR conditions: $94{ }^{\circ} \mathrm{C}$ for $2 \mathrm{~min}$, followed by 35 cycles of $94{ }^{\circ} \mathrm{C}$ for $30 \mathrm{~s}, 50{ }^{\circ} \mathrm{C}$ for $30 \mathrm{~s}$, and $72{ }^{\circ} \mathrm{C}$ for $1 \mathrm{~min}$, followed by a final elongation step at $72{ }^{\circ} \mathrm{C}$ for $5 \mathrm{~min}$. All amplicon products were then purified using Agencourt Ampure beads (Beckman Coulter, Brea, CA, USA), separately amplified with Illumina index primers $\left(94{ }^{\circ} \mathrm{C}\right.$ for 2 min, followed by 8 cycles of $94{ }^{\circ} \mathrm{C}$ for $30 \mathrm{~s}, 55^{\circ} \mathrm{C}$ for $30 \mathrm{~s}$, and $72{ }^{\circ} \mathrm{C}$ for $1 \mathrm{~min}$, followed by a final elongation step at $72{ }^{\circ} \mathrm{C}$ for $5 \mathrm{~min}$ ), purified using Agencourt Ampure beads, quantified (Qubit; Thermo Fisher, Waltham, MA, USA), and pooled in equimolar concentrations. The purified library was then sequenced on an Illumina MiSeq using a v2 300 bp PE sequencing kit following the manufacturer's protocol (Illumina, CA, USA).

Raw Illumina reads were processed using QIIME2 version 2019.10 [52]. Imported paired-end reads were denoised and merged using DADA2 [53] (via q2-dada2), which involved trimming the primer sequences from each read, truncating at $220 \mathrm{bp}$ or $200 \mathrm{bp}$ (R1 and R2 reads, respectively), and de novo chimera detection and removal to produce a set of amplicon sequence variants (ASVs). The ASVs were clustered into de novo OTUs at $97 \%$ similarity using the vsearch clustering algorithm plugin [54]. Representative OTU sequences were classified using the q2-feature-classifier [55] classify-sklearn naive Bayes taxonomy classifier against the SILVA 132 515F/806R reference sequence database.

\subsection{Spearman Correlations}

Significant Spearman correlations $(p \geq 0.05)$ were used to infer the relationship between physicochemical parameters, the amoeba identified, and the bacterial biofilm communities. Data obtained at day 30 were analysed, which includes the 5 physicochemical parameters measured during the study, the biofilm cell counts, 6 amoeba genera detected in samples by qPCR, and 86 OTUs at $97 \%$ cut off. The software used for this purpose was SPSS Statistics 26 (IBM SPSS Statistics for Windows, Version 26.0. Armonk, NY: IBM Corp). The Spearman's rank-order correlation is a nonparametric test that measures the strength and direction of the association between two ranked variables, providing a correlation coefficient signified by rs. The Spearman correlation coefficient, rs, can take values from +1 to -1 as follows: (i) rs of +1 indicates a perfect positive association of ranks, (ii) rs of 
0 indicates no association between ranks, (iii) rs of -1 indicates a perfect negative association of ranks. Therefore, rs values close to +1 indicate a strong positive correlation between the two factors that are analysed, while values close to -1 indicate a strong negative correlation. The closer rs to zero, the weaker the association between the ranks.

\section{Results}

\subsection{Water Characteristics}

The physical and chemical parameters of the recirculated water were fairly consistent across the three loops (Table 1). The $\mathrm{pH}$ values were near neutral throughout the experiment and ranged from 6.70 to 7.40 , while the water temperature ranged from 15.80 to $23.40^{\circ} \mathrm{C}$, which was consistent with the changes in the room temperature. The free chlorine levels were between 0.24 and $0.50 \mathrm{mg} / \mathrm{L}$, with concentrations slightly higher at the beginning of the experiment when the test facility was disinfected with RODOLITE. A similar trend was witnessed for the total chlorine measurements $(0.49-0.70 \mathrm{mg} / \mathrm{L})$. Higher turbidity levels were observed for the first 10 days of the experiment $(0.36-0.70 \mathrm{NTU})$ as a consequence of the increased participles suspended in the new incoming water.

Table 1. Water physico-chemical parameters measured during the experiment. All values represent an average of 3 discrete water samples \pm standard deviation.

\begin{tabular}{|c|c|c|c|c|c|c|}
\hline & & $\begin{array}{l}\text { Water } \\
\text { pH }\end{array}$ & $\begin{array}{c}\text { Water Temperature } \\
\left({ }^{\circ} \mathrm{C}\right)\end{array}$ & $\begin{array}{l}\text { Free Chlorine } \\
\quad(\mathrm{mg} / \mathrm{L})\end{array}$ & $\begin{array}{l}\text { Total Chlorine } \\
(\mathrm{mg} / \mathrm{L})\end{array}$ & $\begin{array}{l}\text { Turbidity } \\
\text { (NTU) }\end{array}$ \\
\hline \multirow{4}{*}{ Loop 1} & Day 0 & $7.37 \pm 0.17$ & $15.80 \pm 0.46$ & $0.50 \pm 0.05$ & $0.67 \pm 0.09$ & $0.53 \pm 0.18$ \\
\hline & Day 10 & $7.34 \pm 0.07$ & $16.17 \pm 0.06$ & $0.33 \pm 0.09$ & $0.41 \pm 0.17$ & $0.70 \pm 0.34$ \\
\hline & Day 20 & $7.33 \pm 0.15$ & $16.80 \pm 0.56$ & $0.26 \pm 0.07$ & $0.33 \pm 0.01$ & $0.40 \pm 0.28$ \\
\hline & Day 30 & $7.40 \pm 0.03$ & $23.40 \pm 0.10$ & $0.29 \pm 0.01$ & $0.30 \pm 0.00$ & $0.11 \pm 0.05$ \\
\hline \multirow{4}{*}{ Loop 2} & Day 0 & $6.91 \pm 0.08$ & $16.30 \pm 0.61$ & $0.44 \pm 0.05$ & $0.59 \pm 0.05$ & $0.47 \pm 0.05$ \\
\hline & Day 10 & $6.70 \pm 0.15$ & $15.97 \pm 0.06$ & $0.50 \pm 0.16$ & $0.44 \pm 0.05$ & $0.53 \pm 0.11$ \\
\hline & Day 20 & $7.04 \pm 0.05$ & $17.00 \pm 0.17$ & $0.24 \pm 0.06$ & $0.32 \pm 0.04$ & $0.28 \pm 0.06$ \\
\hline & Day 30 & $7.00 \pm 0.06$ & $23.30 \pm 0.15$ & $0.30 \pm 0.05$ & $0.36 \pm 0.005$ & $0.13 \pm 0.02$ \\
\hline \multirow{4}{*}{ Loop 3} & Day 0 & $6.92 \pm 0.17$ & $15.87 \pm 0.12$ & $0.32 \pm 0.16$ & $0.47 \pm 0.08$ & $0.36 \pm 0.32$ \\
\hline & Day 10 & $6.96 \pm 0.08$ & $16.00 \pm 0.00$ & $0.31 \pm 0.02$ & $0.46 \pm 0.02$ & $0.49 \pm 0.22$ \\
\hline & Day 20 & $6.98 \pm 0.04$ & $17.03 \pm 0.15$ & $0.28 \pm 0.02$ & $0.31 \pm 0.05$ & $0.37 \pm 0.01$ \\
\hline & Day 30 & $6.70 \pm 0.09$ & $23.23 \pm 0.32$ & $0.26 \pm 0.03$ & $0.32 \pm 0.02$ & $0.12 \pm 0.03$ \\
\hline
\end{tabular}

\subsection{Amoeba Presence and the Total Microbial Community}

At the operational end of the pipe loop experiment, the biofilm and bulk water samples were collected for the analysis of the presence of amoebae. In the bulk water samples, no viable or non-viable amoebae were detected. In the biofilm samples, viable amoebae growing on NNA-E. coli plates were detected in loops 1 and 2 (Table 2). The viable amoebae were identified as Vermamoeba species and Naegleria clarki. The molecular analysis of the amoebae using the total DNA samples detected amoebae in all three loop systems. The non-viable amoebae were multiple Naegleria species as well as Vermamoeba and Acanthamoeba species. All the samples were negative for the presence of pathogenic $N$. fowleri. The total microbial counts in the biofilm samples ranged from $1.69 \times 10^{4}$ to $1.23 \times 10^{6} \mathrm{cells} / \mathrm{cm}^{2}$ (Table 2).

Table 2. Amoebae analysis and total cells in biofilm cells from samples at day 30 .

\begin{tabular}{|c|c|c|c|c|c|}
\hline \multirow{2}{*}{ Sample } & \multirow{2}{*}{ Biofilm Loop } & \multicolumn{2}{|c|}{ NNA Viability and qPCR } & \multirow{2}{*}{ Total DNA qPCR } & \multirow{2}{*}{$\begin{array}{l}\text { Biofilm Total Cells } \\
\left(\text { Cells } / \mathrm{cm}^{2}\right)\end{array}$} \\
\hline & & Room Temperature & $30{ }^{\circ} \mathrm{C}$ & & \\
\hline Biofilm 1 & 1 & NEG & NEG & NEG & $3.37 \times 10^{5}$ \\
\hline Biofilm 2 & 1 & Vermamoeba spp. & Vermamoeba spp. & $\begin{array}{c}\text { Vermamoeba spp., } \\
\text { N. dobsoni, N. australiensis }\end{array}$ & $1.23 \times 10^{6}$ \\
\hline Biofilm 3 & 1 & Vermamoeba spp. & NEG & $\begin{array}{c}\text { N. australiensis, N. clarki, } \\
\text { Acanthamoeba spp. }\end{array}$ & $3.50 \times 10^{5}$ \\
\hline
\end{tabular}


Table 2. Cont.

\begin{tabular}{|c|c|c|c|c|c|}
\hline \multirow{2}{*}{ Sample } & \multirow{2}{*}{ Biofilm Loop } & \multicolumn{2}{|c|}{ NNA Viability and qPCR } & \multirow{2}{*}{ Total DNA qPCR } & \multirow{2}{*}{$\begin{array}{l}\text { Biofilm Total Cells } \\
\left(\text { Cells } / \mathrm{cm}^{2}\right)\end{array}$} \\
\hline & & Room Temperature & $30{ }^{\circ} \mathrm{C}$ & & \\
\hline Biofilm 4 & 2 & NEG & N. clarki & NEG & $2.62 \times 10^{5}$ \\
\hline Biofilm 5 & 2 & NEG & NEG & N. dobsoni & $2.89 \times 10^{5}$ \\
\hline Biofilm 6 & 2 & NEG & NEG & N. dobsoni & $1.69 \times 10^{4}$ \\
\hline Biofilm 7 & 3 & NEG & NEG & N. australiensis & $1.65 \times 10^{5}$ \\
\hline Biofilm 8 & 3 & NEG & NEG & N. australiensis & $1.84 \times 10^{5}$ \\
\hline Biofilm 9 & 3 & NEG & NEG & N. lovaniensis & $2.70 \times 10^{5}$ \\
\hline
\end{tabular}

NEG stands for negative result.

\subsection{Bacterial Community Analysis in Biofilm Samples}

The bacteria community analysis (Figure 3) showed a clear difference between the loops despite being fed with the same local source of drinking water during the experimental growth and a $24 \mathrm{~h}$ water retention time for all the loops. The main difference between the communities was observed in loop 3, with a very high relative abundance of Pseudomonas in two of the replicate samples $(>68 \%)$ and with a high abundance of Cupriavidus in the replicate $1(77 \%)$. The concentration of free chlorine was less in loop 3 (average $=0.29 \mathrm{mg} / \mathrm{L}, n=12$ ) during the growth phase when compared with the other loops (loop 1 average $=0.34 \mathrm{mg} / \mathrm{L}$ and loop 2 average $0.37 \mathrm{mg} / \mathrm{L} ; n=12$ for each loop); this was the main characteristic in the bulk water that could explain the differences in the replicates of loop 3 when compared with the other loops, yet the high levels of Cupriavidus in replicate 1 are unique when compared with the other samples. However, other parameters in the bulk water that could have influenced this result, such as the total organic carbon (TOC), were not measured during the experiment.
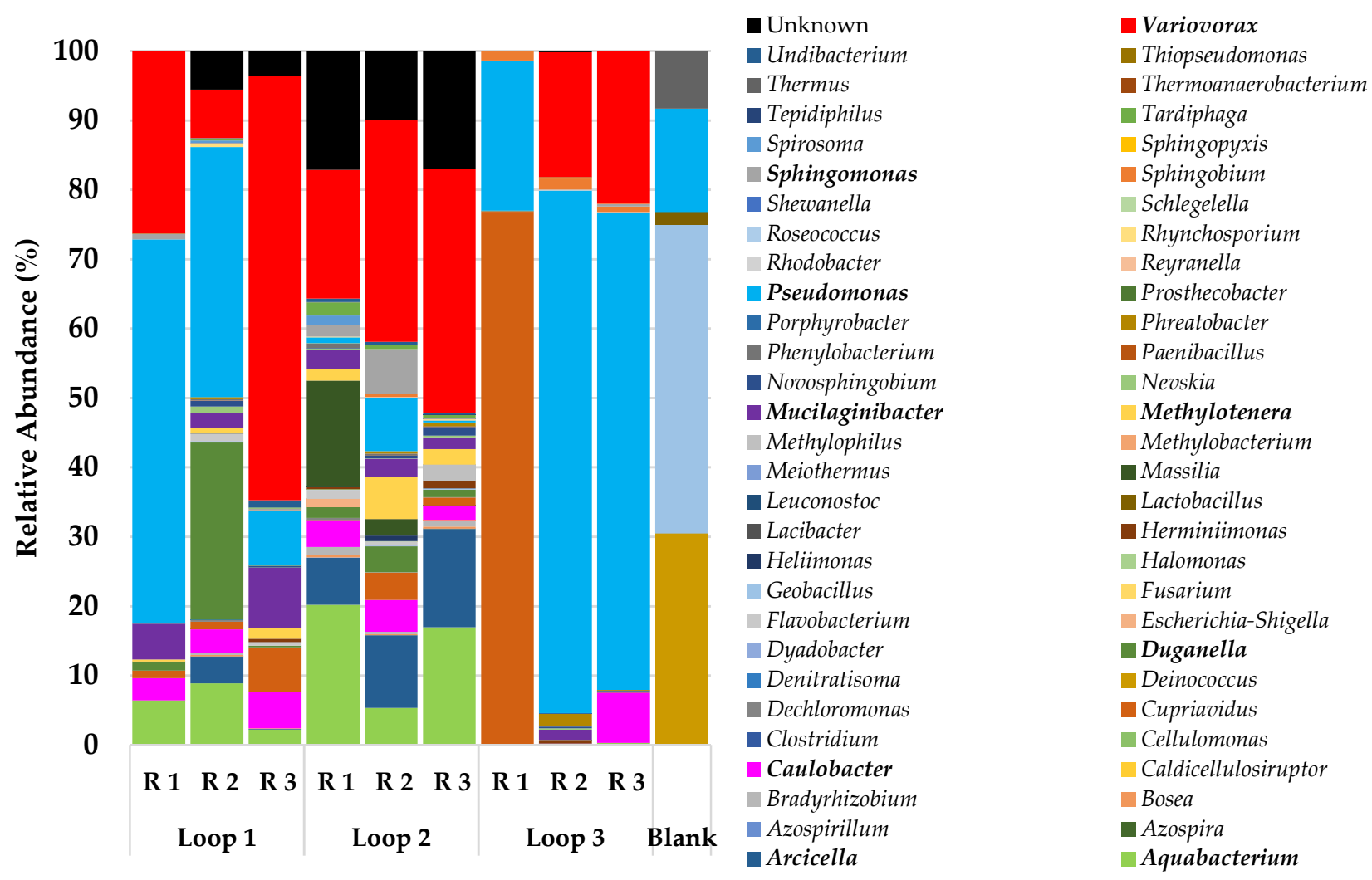

Figure 3. Relative abundance of the main bacteria genera in the biofilm samples. 
Overall, the predominant bacteria genera in all the biofilm samples were Pseudomonas (21-75\%), followed by Variovorax (5-26\%) and Aquabacterium (2-20\%). Several genera were present in most of the samples but with a relative abundance of less than $5 \%$, such as Methylotenera, Sphingomonas, Arcicella, and Cupriavidus.

\subsection{Correlation between Physicochemical and Microbial Parameters}

Spearman's correlations (Table S1) indicated that most of the amoeba genera detected in the samples showed significant correlations $(p<0.05)$ with a bacterial OTU, especially $N$. dobsoni. The relative abundance of these OTUs did not exceed the $4 \%$ in any case, and most of them belonged to Alphaproteobacteria and to the Sphingomonadaceae family. Regarding the genus Vermamoeba, although it did not present correlations with any bacterial OTUs, it did have a significant positive correlation with the total number of cells counted in the biofilm. Concerning the physicochemical parameters, only the turbidity was significantly correlated with two species of amoebae, positively with $N$. dobsoni and negatively with $N$. clarki.

\section{Discussion}

Amoebae have been previously found in DWDS, and some of them cause fatal infections, such as $N$. fowleri. In this study, the chlorine disinfectant residual levels were consistent with the operational water quality targets (free chlorine $0.2-0.5 \mathrm{mg} / \mathrm{L}$ ) in the water and a maximum temperature of $23.4{ }^{\circ} \mathrm{C}$; amoebae were only found in biofilms and not in planktonic communities. It has been hypothesised that suboptimal chlorine residuals enable the increase of the microbial richness, the presence of specific microbial taxa, and can also influence the presence of amoebae.

The bulk water and biofilm were assessed for the presence of FLA using viable and molecular testing methods. Thermophilic N. fowleri was not detected in this study; this amoeba is typically isolated from warmer waters with lower free chlorine residuals. Viable Vermamoeba spp. and another Naegleria spp., N. clarki, were detected in loops 1 and 2, respectively, with no viable FLA detected in loop 3. Due to the similarities in the physical and chemical characteristics across the 3 loops, we cannot ascertain their influence on the presence of the specific amoebae in each of the loops. When looking at the molecular detections, we see that loop 1 had detections for multiple FLA, including pathogenic Acanthamoeba spp.; however, only Vermamoeba spp. was detected viably at the 30-day sample point. This could suggest a state of flux for loop 1 where multiple species are incoming but only one is able to fully colonise the biofilm of the pipe at any given time. This is consistent with Miller, Wylie, et al. (2018), who found that competition between co-colonising amoebae exists and proposes that the result of such competition may be reliant on the surrounding bacterial community [47].

When assessing the biofilm bacterial communities, all the replicates had above $10^{4}$ cells $/ \mathrm{mL}$, meaning that all the samples had sufficient bacterial richness to support $N$. fowleri growth $[28,56]$. When looking more closely at the composition of the biofilm bacterial communities, Proteobacteria dominated across all the loops, yet there were differences in the composition of the less abundant community members between the loops. Carpitella et al. (2020) showed that it is not always the most abundant microorganisms that play a key role in determining the DWDS processes [57]. Thus, these "rare" community members could be influencers on the presence of specific FLA in a given biofilm, as observed in the Spearman correlations. Miller, Morgan, et al. (2018) have found that Meiothermus, although not a major component of the DWDS biofilms in this study, is a food source and has a significant co-occurrence with $N$. fowleri, indicating its potential role in enabling $N$. fowleri colonisation to occur [48]. This means that certain bacteria, not always the most abundant members, can favour the presence of amoebae, as was observed in this study with Vermamoeba spp. or Naegleria spp. in loops 1 and 2. Sphingomonadaceae has been previously related with FLA; some studies of DWDS have indicated negative associations between this bacterial family and amoebae [48]; meanwhile, others have described that 
these microorganisms tend to be concurrent [58]. Several significant correlations were established between some amoeba species ( $N$. dobsoni and N. australis) and the OTUs of the Sphingomonadaceae family; thus, these bacterial members could influence the distribution of the FLA in DWDS.

Another aspect that needs to be considered is that the detected amoebae are known to act as reservoirs for drinking water pathogenic bacteria, such as Legionella or Mycobacterium [59]. The main bacterial genera found in this study was Pseudomonas, which is one of the main members of biofilms in UK chlorinated DWDS, associated with different types of pipe materials and hydraulic conditions [60]. Previous studies have analysed the interaction between amoebae and Pseudomonas spp., establishing that amoebae, such as Acanthamoeba spp., can feed on this microorganism, while some species are resistant to amoebae [26]. Therefore, FLA can act as a reservoir for amoeba-resistant strains of Pseudomonas, including several opportunistic pathogens that belong to this genus. Regarding the other two most representative genera, Variovorax and Aquabacterium, they have been described in previous studies of FLA and bacteria in drinking water [58]. It has been reported that several members of the Variovorax genus are endosymbionts of amoebae, such as Arcella rotundata [61], Acanthamoeba, or Saccamoeba lacustris [62]. Aquabacterium is a genus highly abundant in DWDS, especially in biofilms $[63,64]$, but, to the best of our knowledge, no relationship has been established between this bacterium and the amoebae characterised in this study before. Considering this, further studies on the interactions of amoebae with mixed species biofilms and not just a limited number of pathogenic microbial species are also needed to better understand the range and complexity of the interactions between amoebae and bacteria. If amoebae feed on biofilms, they do not only transport pathogens but they can also help to disseminate the biofilm-associated processes in DWDS, such as virulence factors, genes resistant to disinfection, and antibiotics [65]. Further studies in UK chlorinated systems are needed to verify whether pathogenic bacteria coexist within the biofilm in chlorinated DWDS, as well as to determine if these harmful microorganisms have become part of the amoebae microbiota.

Monitoring in the UK in searching for the FLA in DWDS is certainly limited. This is likely because the UK is a temperate region, meaning that pathogenic thermophilic amoebae are not likely to be present due to the lower temperatures. However, climate change has resulted in rises in the average global temperature, and the prediction models suggest that this trend will continue [66]. This has already resulted in thermophilic amoebae being isolated from temperate regions, which was previously not thought possible [67], and a northern expansion of the range of PAM deaths in the USA [32], which may explain the recent outbreak of AK described in the UK. Europe and the UK will continue to become warmer and may also see increased precipitation, which may favour $N$. fowleri colonisation and the spread of PAM [19]. For this reason, the surveillance of the FLA in UK DWDS is becoming more important to ensure the continued safety of consumers. In addition, the results here detected amoebae in the biofilm, not the bulk water. As biofilm is the known reservoir for amoebae [26], the need to better monitor biofilm and biofilm-associated organisms in operational DWDS needs to be addressed.

\section{Conclusions}

The biofilm samples contained multiple amoebae (viable and non-viable), which are potential pathogens and able to support the presence of ARB. Amoebae were not detected in the bulk water samples, but its detection in the biofilm samples implies a potential risk of the mobilisation of these microorganisms into the bulk water through changes in the hydraulic conditions or through migration. The studied biofilms also had a high relative abundance of potential opportunistic pathogens, including Pseudomonas. Further studies are needed to assess the presence, abundance, and composition of amoebae and associated bacteria and mixed species biofilms in the UK water supply systems as well as potential changes in their presence due to climate change impacts. 
Supplementary Materials: The following are available online at https:/ / www.mdpi.com/article/10 $.3390 / w 13213069$ /s1, Table S1: Spearman correlations between physi-cochemical parameters, the amoeba identified, and the bacterial biofilm communities at day 30 .

Author Contributions: Conceptualisation: I.D., C.C. and G.J.P.; methodology, software, and validation: G.J.P., C.C., I.D., M.J.M. and N.M.; formal analysis and investigation: G.D.O., C.C., G.J.P., M.J.M. and N.M.; resources and data curation: G.D.O., C.C., G.J.P., M.J.M. and N.M.; writing-original draft preparation: G.D.O., G.J.P. and I.D.; writing—review and editing: G.D.O., G.J.P., M.J.M., N.M. and I.D. All authors have read and agreed to the published version of the manuscript.

Funding: This research was funded by the UK Engineering and Physical Sciences Research Council (EPSRC). EPSRC-LWEC Challenge Fellowship EP/N02950X/1.

Institutional Review Board Statement: Not applicable.

Informed Consent Statement: Not applicable.

Data Availability Statement: Data have been published and access is available at https:/ / doi.org / 10.25919/131d-sj06.

Acknowledgments: Tom Walsh, Suzanne Metcalfe, and Jason Wylie are thanked for their technical support.

Conflicts of Interest: The authors declare no conflict of interest.

\section{References}

1. Samba-Louaka, A.; Delafont, V.; Rodier, M.H.; Cateau, E.; Héchard, Y. Free-living amoebae and squatters in the wild: Ecological and molecular features. FEMS Microbiol. Rev. 2019, 43, 415-434. [CrossRef]

2. Paszko-Kolva, C.; Yamamoto, H.; Shahamat, M.; Sawyer, T.K.; Morris, G.; Colwell, R.R. Isolation of amoebae and Pseudomonas and Legionella spp. from eyewash stations. Appl. Environ. Microbiol. 1991, 57, 163-167. [CrossRef] [PubMed]

3. Page, F.C. An Illustrated Key to Freshwater and Soil Amoebae: With Notes on Cultivation and Ecology; Freshwater Biological Association: Ambleside, UK, 1976; ISBN-10 9780900386268.

4. Masangkay, F.; Milanez, G.; Karanis, P.; Nissapatorn, V. Vermamoeba vermiformis-global trend and future perspective. In Encyclopedia of Environmental Health; Nriagu, J.O., Ed.; Elsevier: New York, NY, USA, 2019; pp. 356-366, ISBN 9780444639523.

5. Schuster, F.L.; Visvesvara, G.S. Free-living amoebae as opportunistic and non-opportunistic pathogens of humans and animals. Int. J. Parasitol. 2004, 34, 1001-1027. [CrossRef] [PubMed]

6. Visvesvara, G.S.; Moura, H.; Schuster, F.L. Pathogenic and opportunistic free-living amoebae: Acanthamoeba spp., Balamuthia mandrillaris, Naegleria fowleri, and Sappinia diploidea. FEMS Immunol. Med. Microbiol. 2007, 50, 1-26. [CrossRef]

7. Cain, A.R.; Wiley, P.F.; Brownell, B.; Warhurst, D.C. Primary amoebic meningoencephalitis. Arch. Dis. Child. 1981, 56, 140-143. [CrossRef]

8. Symmers, W.S. Primary Amoebic Meningoencephalitis in Britain. Br. Med. J. 1969, 4, 449-454. [CrossRef]

9. Seal, D.; Stapleton, F.; Dart, J. Possible environmental sources of Acanthamoeba spp in contact lens wearers. Br. J. Ophthalmol. 1992, 76, 424-427. [CrossRef]

10. Bacon, A.S.; Frazer, D.G.; Dart, J.K.; Matheson, A.S.; Ficker, L.A.; Wright, P. A review of 72 consecutive cases of acanthamoeba keratitis, 1984-1992. Eye 1993, 7, 719-725. [CrossRef]

11. Radford, C.F.; Minassian, D.C.; Dart, J.K. Acanthamoeba keratitis in England and Wales: Incidence, outcome, and risk factors. Br. J. Ophthalmol. 2002, 86, 536-542. [CrossRef] [PubMed]

12. Kilvington, S.; Gray, T.; Dart, J.; Morlet, N.; Beeching, J.R.; Frazer, D.G.; Matheson, M. Acanthamoeba Keratitis: The Role of Domestic Tap Water Contamination in the United Kingdom. Investig. Ophthalmol. Vis. Sci. 2004, 45, 165-169. [CrossRef]

13. Chawla, A.; Armstrong, M.; Carley, F. Acanthamoeba keratitis-An increasing incidence. Contact Lens Anterior Eye 2014, 37, 120. [CrossRef]

14. Carnt, N.; Robaei, D.; Minassian, D.C.; Dart, J.K. Acanthamoeba keratitis in 194 patients: Risk factors for bad outcomes and severe inflammatory complications. Br. J. Ophthalmol. 2018, 102, 1431-1435. [CrossRef]

15. Carnt, N.; Hoffman, J.J.; Verma, S.; Hau, S.; Radford, C.F.; Minassian, D.C.; Dart, J.K. Acanthamoeba keratitis: Confirmation of the UK outbreak and a prospective case-control study identifying contributing risk factors. Br. J. Ophthalmol. 2018, 102, 1621-1628. [CrossRef]

16. Hassan, F.; Bhatti, A.; Desai, R.; Barua, A. Analysis from a year of increased cases of Acanthamoeba Keratitis in a large teaching hospital in the UK. Contact Lens Anterior Eye 2019, 42, 506-511. [CrossRef]

17. Carnt, N.A.; Subedi, D.; Connor, S.; Kilvington, S. The relationship between environmental sources and the susceptibility of Acanthamoeba keratitis in the United Kingdom. PLoS ONE 2020, 15, e229681. [CrossRef]

18. Höllhumer, R.; Keay, L.; Watson, S.L. Acanthamoeba keratitis in Australia: Demographics, associated factors, presentation and outcomes: A 15-year case review. Eye 2020, 34, 725-732. [CrossRef] 
19. Maciver, S.K.; Piñero, J.E.; Lorenzo-Morales, J. Is Naegleria fowleri an Emerging Parasite? Trends Parasitol. 2020, 36, 19-28. [CrossRef]

20. Ma, P.; Visvesvara, G.S.; Martinez, A.J.; Theodore, F.H.; Daggett, P.M.; Sawyer, T.K. Naegleria and acanthamoeba infections: Review. Clin. Infect. Dis. 1990, 12, 490-513. [CrossRef]

21. Cope, J.R.; Ali, I.K. Primary Amebic Meningoencephalitis: What Have We Learned in the Last 5 Years? Curr. Infect. Dis. Rep. 2016, 18, 31. [CrossRef]

22. Dorsch, M.M.; Branch, E.; South Australian Health Commission. Primary Amoebic Meningoencephalitis: An Historical and Epidemiological Perspective with Particular Reference to South Australia; Epidemiology Branch South Australian Health Commision: Adelaide, Australia, 1982.

23. Gharpure, R.; Bliton, J.; Goodman, A.; Ali, I.K.; Yoder, J.; Cope, J.R. Epidemiology and Clinical Characteristics of Primary Amebic Meningoencephalitis Caused by Naegleria fowleri: A Global Review. Clin. Infect. Dis. 2020, 73, e19-e27. [CrossRef]

24. Patel, A.; Hammersmith, K. Contact lens-related microbial keratitis: Recent outbreaks. Curr. Opin. Ophthalmol. 2008, 19, 302-306. [CrossRef]

25. Stehr-Green, J.K.; Bailey, T.M.; Visvesvara, G.S. The Epidemiology of Acanthamoeba Keratitis in the United States. Am. J. Ophthalmol. 1989, 107, 331-336. [CrossRef]

26. Puzon, G.J.; Miller, H.C.; Malinowski, N.; Walsh, T.; Morgan, M.J. Naegleria fowleri in drinking water distribution systems. Curr. Opin. Environ. Sci. Health 2020, 16, 22-27. [CrossRef]

27. Huang, J.; Chen, S.; Ma, X.; Yu, P.; Zuo, P.; Shi, B.; Wang, H.; Alvarez, P.J. Opportunistic pathogens and their health risk in four full-scale drinking water treatment and distribution systems. Ecol. Eng. 2021, 160, 106134. [CrossRef]

28. Morgan, M.J.; Halstrom, S.; Wylie, J.T.; Walsh, T.; Kaksonen, A.H.; Sutton, D.; Braun, K.; Puzon, G.J. Characterization of a Drinking Water Distribution Pipeline Terminally Colonized by Naegleria fowleri. Environ. Sci. Technol. 2016, 50, 2890-2898. [CrossRef]

29. Flemming, H.C.; Percival, S.L.; Walker, J.T. Contamination potential of biofilms in water distribution systems. Water Sci. Technol. Water Supply 2002, 2, 271-280. [CrossRef]

30. Hoffmann, R.; Michel, R. Distribution of free-living amoebae (FLA) during preparation and supply of drinking water. Int. J. Hyg. Environ. Health 2001, 203, 215-219. [CrossRef]

31. Cooper, A.M.; Aouthmany, S.; Shah, K.; Rega, P.P. Killer amoebas: Primary amoebic meningoencephalitis in a changing climate. J. Am. Acad. Physician Assist. 2019, 32, 30-35. [CrossRef] [PubMed]

32. Gharpure, R.; Gleason, M.; Salah, Z.; Blackstock, A.J.; Hess-Homeier, D.; Yoder, J.S.; Ali, I.K.; Collier, S.A.; Cope, J.R. Geographic range of recreational water-associated primary amebic meningoencephalitis, United States, 1978-2018. Emerg. Infect. Dis. 2021, 27, 271-274. [CrossRef]

33. Siddiqui, R.; Khan, N.A. Biology and pathogenesis of Acanthamoeba. Parasites Vectors 2012, 5, 6. [CrossRef]

34. Thomas, V.; McDonnell, G.; Denyer, S.P.; Maillard, J.Y. Free-living amoebae and their intracellular pathogenic microorganisms: Risks for water quality. FEMS Microbiol. Rev. 2010, 34, 231-259. [CrossRef]

35. Scheid, P. Free-Living Amoebae as Human Parasites and Hosts for Pathogenic Microorganisms. Proceedings 2018, 2, 692. [CrossRef]

36. Balczun, C.; Scheid, P.L. Free-living amoebae as hosts for and vectors of intracellular microorganisms with public health significance. Viruses 2017, 9, 65. [CrossRef]

37. Greub, G.; Raoult, D. Microorganisms Resistant to Free-Living Amoebae. Clin. Microbiol. Rev. 2004, 17, 413-433. [CrossRef] [PubMed]

38. de Souza, T.K.; Soares, S.S.; Benitez, L.B.; Rott, M.B. Interaction Between Methicillin-Resistant Staphylococcus aureus (MRSA) and Acanthamoeba polyphaga. Curr. Microbiol. 2017, 74, 541-549. [CrossRef]

39. Cirillo, J.D.; Falkow, S.; Tompkins, L.S. Growth of Legionella pneumophila in Acanthamoeba castellanii enhances invasion. Infect. Immun. 1994, 62, 3254-3261. [CrossRef] [PubMed]

40. Cirillo, J.D.; Falkow, S.; Tompkins, L.S.; Bermudez, L.E. Interaction of Mycobacterium avium with environmental amoebae enhances virulence. Infect. Immun. 1997, 65, 3759-3767. [CrossRef] [PubMed]

41. Nora, T.; Lomma, M.; Gomez-Valero, L.; Buchrieser, C. Molecular mimicry: An important virulence strategy employed by Legionella pneumophila to subvert host functions. Future Microbiol. 2009, 4, 691-701. [CrossRef]

42. WHO. WHO Drinking Water Guideline; World Health Organisation Chronicle; WHO: Geneva, Switzerland, 2017; ISBN 9789241549950.

43. Douterelo, I.; Fish, K.E.; Boxall, J.B. Succession of bacterial and fungal communities within biofilms of a chlorinated drinking water distribution system. Water Res. 2018, 141, 74-85. [CrossRef] [PubMed]

44. Deines, P.; Sekar, R.; Husband, P.S.; Boxall, J.B.; Osborn, A.M.; Biggs, C.A. A new coupon design for simultaneous analysis of in situ microbial biofilm formation and community structure in drinking water distribution systems. Appl. Microbiol. Biotechnol. 2010, 87, 749-756. [CrossRef] [PubMed]

45. Miller, H.C.; Wylie, J.; Dejean, G.; Kaksonen, A.H.; Sutton, D.; Braun, K.; Puzon, G.J. Reduced Efficiency of Chlorine Disinfection of Naegleria fowleri in a Drinking Water Distribution Biofilm. Environ. Sci. Technol. 2015, 49, 11125-11131. [CrossRef] [PubMed]

46. Puzon, G.J.; Lancaster, J.A.; Wylie, J.T.; Plumb, J.J. Rapid detection of Naegleria fowleri in water distribution pipeline biofilms and drinking water samples. Environ. Sci. Technol. 2009, 43, 6691-6696. [CrossRef]

47. Miller, H.C.; Wylie, J.T.; Kaksonen, A.H.; Sutton, D.; Puzon, G.J. Competition between Naegleria fowleri and Free Living Amoeba Colonizing Laboratory Scale and Operational Drinking Water Distribution Systems. Environ. Sci. Technol. 2018, 52, $2549-2557$. [CrossRef] [PubMed] 
48. Miller, H.C.; Morgan, M.J.; Walsh, T.; Wylie, J.T.; Kaksonen, A.H.; Puzon, G.J. Preferential feeding in Naegleria fowleri; intracellular bacteria isolated from amoebae in operational drinking water distribution systems. Water Res. 2018, 141, 126-134. [CrossRef]

49. Pélandakis, M.; Serre, S.; Pernin, P. Analysis of the 5.8S rRNA gene and the internal transcribed spacers in Naegleria spp. and in N. fowleri. J. Eukaryot. Microbiol. 2000, 47, 116-121. [CrossRef] [PubMed]

50. Schroeder, J.M.; Booton, G.C.; Hay, J.; Niszl, I.A.; Seal, D.V.; Markus, M.B.; Fuerst, P.A.; Byers, T.J. Use of subgenic 18S ribosomal DNA PCR and sequencing for genus and genotype identification of Acanthamoebae from humans with keratitis and from sewage sludge. J. Clin. Microbiol. 2001, 39, 1903-1911. [CrossRef]

51. Bruckberger, M.C.; Gleeson, D.B.; Bastow, T.P.; Morgan, M.J.; Walsh, T.; Rayner, J.L.; Davis, G.B.; Puzon, G.J. Unravelling microbial communities associated with different light non-aqueous phase liquid types undergoing natural source zone depletion processes at a legacy petroleum site. Water 2021, 13, 898. [CrossRef]

52. Bolyen, E.; Rideout, J.R.; Dillon, M.R.; Bokulich, N.A.; Abnet, C.C.; Al-Ghalith, G.A.; Alexander, H.; Alm, E.J.; Arumugam, M.; Asnicar, F.; et al. Reproducible, interactive, scalable and extensible microbiome data science using QIIME 2. Nat. Biotechnol. 2019, 37, 852-857. [CrossRef]

53. Callahan, B.J.; McMurdie, P.J.; Rosen, M.J.; Han, A.W.; Johnson, A.J.A.; Holmes, S.P. DADA2: High-resolution sample inference from Illumina amplicon data. Nat. Methods 2016, 13, 581-583. [CrossRef]

54. Rognes, T.; Flouri, T.; Nichols, B.; Quince, C.; Mahé, F. VSEARCH: A versatile open source tool for metagenomics. PeerJ 2016, 4, e2584. [CrossRef]

55. Bokulich, N.A.; Kaehler, B.D.; Rideout, J.R.; Dillon, M.; Bolyen, E.; Knight, R.; Huttley, G.A.; Gregory Caporaso, J. Optimizing taxonomic classification of marker-gene amplicon sequences with QIIME 2's q2-feature-classifier plugin. Microbiome 2018, 6, 90. [CrossRef]

56. Goudot, S.; Herbelin, P.; Mathieu, L.; Soreau, S.; Banas, S.; Jorand, F. Growth dynamic of Naegleria fowleri in a microbial freshwater biofilm. Water Res. 2012, 46, 3958-3966. [CrossRef]

57. Carpitella, S.; Del Olmo, G.; Izquierdo, J.; Husband, S.; Boxall, J.; Douterelo, I. Decision-making tools to manage the microbiology of drinking water distribution systems. Water 2020, 12, 1247. [CrossRef]

58. Delafont, V.; Brouke, A.; Bouchon, D.; Moulin, L.; Héchard, Y. Microbiome of free-living amoebae isolated from drinking water. Water Res. 2013, 47, 6958-6965. [CrossRef]

59. Wang, H.; Edwards, M.; Falkinham, J.O.; Pruden, A. Molecular survey of the occurrence of Legionella spp., Mycobacterium spp., Pseudomonas aeruginosa, and amoeba hosts in two chloraminated drinking water distribution systems. Appl. Environ. Microbiol. 2012, 78, 6285-6294. [CrossRef] [PubMed]

60. Douterelo, I.; Sharpe, R.L.; Husband, S.; Fish, K.E.; Boxall, J.B. Understanding microbial ecology to improve management of drinking water distribution systems. Wiley Interdiscip. Rev. Water 2019, 6, e01325. [CrossRef]

61. Török, J.K.; Pollák, B.; Heéger, Z.; Csikós, G.; Márialigeti, K. First evidence of bacterial endocytobionts in the lobose testate amoeba Arcella (Amoebozoa, arcellinida). Protistology 2008, 5, 303-312.

62. Corsaro, D.; Michel, R.; Walochnik, J.; Müller, K.D.; Greub, G. Saccamoeba lacustris, sp. nov. (Amoebozoa: Lobosea: Hartmannellidae), a new lobose amoeba, parasitized by the novel chlamydia 'Candidatus Metachlamydia lacustris' (Chlamydiae: Parachlamydiaceae). Eur. J. Protistol. 2010, 46, 86-95. [CrossRef]

63. Kalmbach, S.; Manz, W.; Bendinger, B.; Szewzyk, U. In situ probing reveals Aquabacterium commune as a widespread and highly abundant bacterial species in drinking water biofilms. Water Res. 2000, 34, 575-581. [CrossRef]

64. Kalmbach, S.; Manz, W.; Wecke, J.; Szewzyk, U. Aquabacterium gen. nov., with description of Aquabacterium citratiphilum sp. nov., Aquabacterium paroum sp. nov. and Aquabacterium commune sp. nov., three in situ dominant bacterial species from the Berlin drinking water system. Int. J. Syst. Evol. Microbiol. 1999, 49, 769-777. [CrossRef]

65. Douterelo, I.; Calero-Preciado, C.; Soria-Carrasco, V.; Boxall, J.B. Whole metagenome sequencing of chlorinated drinking water distribution systems. Environ. Sci. Water Res. Technol. 2018, 4, 2080-2091. [CrossRef]

66. CSIRO \&The Bureau of Meteorology. State of the Climate 2020; Australian Gobernment: Canberra, Australia, 2020.

67. Kemble, S.K.; Lynfield, R.; DeVries, A.S.; Drehner, D.M.; Pomputius, W.F.; Beach, M.J.; Visvesvara, G.S.; Da Silva, A.J.; Hill, V.R.; Yoder, J.S.; et al. Fatal Naegleria fowleri infection acquired in minnesota: Possible expanded range of a deadly thermophilic organism. Clin. Infect. Dis. 2012, 54, 805-809. [CrossRef] [PubMed] 